\title{
Antidunes on steep slopes
}

2

3 A. Recking, Researcher, Cemagref, UR Erosion Torrentielle Neige Avalanches, 2 rue de la

4 papeterie, BP76, 38402 Saint Martin d'Hères, France. E-mail: alain.recking@ cemagref.fr

5

6 V. Bacchi, phD Student, Cemagref, UR Erosion Torrentielle Neige Avalanches, 2 rue de la

7 papeterie, BP76, 38402 Saint Martin d'Hères, France. E-mail: vito.bacchi@ cemagref.fr

8

9 M. Naaim, Researcher, Cemagref, UR Erosion Torrentielle Neige Avalanches, 2 rue de la 10 papeterie, BP76, 38402 Saint Martin d'Hères, France. E-mail: mohamed.naaim@cemagref.fr 11

12 P. Frey, Researcher, Cemagref, UR Erosion Torrentielle Neige Avalanches, 2 rue de la 13 papeterie, BP76, 38402 Saint Martin d'Hères, France. E-mail: philippe.frey@ cemagref.fr

14

15 


\section{ABSTRACT}

17 When increasing the rates of subcritical flow on gentle slopes, the bed successively produces ripples, dunes and flat beds. Antidunes (defined here as all bed undulations for which the surface gravity waves are in phase with the bed profile) appear only in high flow rates and may be found in some extreme natural flow events. Inversely, on steep slopes flume experiment ( $S \geq 1 \%$ approximately) flows are supercritical and antidunes were observed to appear just after the beginning of sediment motion and to disappear for high flow rates. With new experiments, this study aimed to improve the prediction of antidune geometry on steep slopes. An equation for antidune wavelength was deduced from dimensional analysis and fitted to new experimental data. The equation was successfully evaluated using a data set extended to 167 values with data from the literature, obtained on both steep and gentle slopes. This equation gave results very similar to the usual analytical equation from Kennedy when tested on the results from gentle slope experiments, but proved to be better adapted for antidune wavelength on steep slopes. 
32 Flows over natural sediments generally develop bedforms consisting of ripples, dunes and antidunes [Engelund and Hansen, 1967; Gilbert, 1914; Van Rijn, 1984]. Ripples and dunes are downstream migrating bedforms that are triangular in shape with a gently sloping upstream face and a downstream face the slope of which nearly equal the sediment's angle of repose. Antidunes have an approximate sinusoidal shape that is usually characterized by a wave length $L$ and an amplitude $A$ (Figure 1). They were first called antidunes by Gilbert [1914] because they contrast with dunes in their direction of movement. Kennedy [1960] also observed downstream migrating antidunes and extended this term to all forms for which the surface gravity waves are in phase with the bed profile. This definition (including nonmoving sinusoidal shapes) will be considered here. Occurrence of dunes and antidunes depends on the sediment and flow properties. It is generally admitted that ripples are associated with smooth turbulent subcritical flows and dunes are associated with rough turbulent subcritical flows, whereas antidunes are associated with supercritical flows. A better comprehension of the mechanisms controlling bedforms is very important because they are associated with the complex behaviour of both the flow resistance and bedload transport equations. More particularly, a better prediction of antidune geometry can help to analyse local scouring associated with hydraulic structures [Comiti and Lenzi, 2006] and to interpret paleo-floods [Shaw and Kellerhals, 1977]. Antidune models also represent one (of several) possible mechanisms which may explain the formation of step-pool morphologies in gravel-bed streams [Chin, 1999; Curran, 2007; Lenzi, 2001; Weichert, et al., 2008; Whittaker and Jaeggi, 1982].

Several theoretical developments on flow domains pertaining to antidunes were proposed during the last decades [Carling and Shvidchenko, 2002; Colombini, 2004; Colombini and 
Stocchino, 2005; 2008; Deigaard, 2008; Engelund, 1970; Hayashi, 1970; Hayashi and

Onishi, 1983; Huang and Chiang, 2001; Kennedy, 1960; Kubo and Yokokawa, 2001; Parker, 1975; Raudkivi, 1966; Reynolds, 1965; Sammarco, et al., 2006]. All these developments considered analytical solutions for the equations governing the mean flow velocity and sediment bedload transport rate. However, the observations and equations were essentially based on gentle slope experiments. On gentle slopes with fine sands, the bed successively produces ripples, dunes and the flat beds close to transition when increasing the subcritical flow rates. Antidunes appear only for very high flow rates (in the upper regime as defined by Simons and Richardson [1966]) and may characterise extreme natural events. On steep slopes ( $S>1 \%$ approximately) antidunes were also observed for intense sediment transport [Foley, 1975; Smart and Jaeggi, 1983] but in these (near) supercritical flows, antidunes (as defined above, i.e., a free surface and upper bed layer in phase) were also observed for relatively low flow conditions both in the field (Figure 2 shows antidunes observed on the Arveyron river in june 2009 whereas the flow discharge was estimated to be half the 2 years RI discharge $\mathrm{Q}_{2}$ ) and in the flume [Bathurst, et al., 1982a; Cao, 1985; Comiti and Lenzi, 2006; Recking, et al., 2008a; Shaw and Kellerhals, 1977]. Figure 3 presents the images of antidunes obtained with a uniform gravel measuring $4.9 \mathrm{~mm}$ in diameter on a $5 \%$ slope as part of the steep slope experiments (143 runs) presented in Recking et al [2008a]. This figure shows that for this experiment, antidunes appear very close to the incipient motion flow condition (characterized here by the ratio between the Shields number $\theta$ and its critical value for incipient motion $\theta_{c}$ ) and that wavelength increased when bed load increased, resulting in a flatter bed as the Shields number increased until the bed become perfectly flat. The shields number is the dimensionless shear stress defined by:

$$
\theta=\frac{\tau}{g\left(\rho_{s}-\rho\right) D}=\frac{\rho g R_{b} S}{g\left(\rho_{s}-\rho\right) D}=\frac{R_{b}}{D} \frac{S}{(s-1)}
$$


where $\tau$ is the bed shear stress, $R_{\mathrm{b}}$ is the bed hydraulic radius, $D$ is the grain diameter, $\rho_{s}$ is the sediment density, $\rho$ is the water density and $s=\rho_{s} / \rho$ is the relative density. The free surface and bed deformation are maximum for approximately $\theta / \theta_{c}=1.5$ (suggesting that on steep slopes, antidunes could arise in many natural floods, at least on the rising and falling limbs of the hydrograph), whereas in Simons and Richardson [1966]'s experiments antidunes were observed for $\theta / \theta_{c}$ values in the [20-90] range. In both steep and gentle slope experiments, antidunes were obtained in supercritical flows, but for very different transport rates and flow relative depth. This paper aims to verify wether these changing flow conditions affect the antidune geometry by comparing antidunes produced on gentle and steep slopes. More particularly, we will investigate whether wavelength equations proposed for gentle slope flows remain valid on steep slopes, where the flow depth $h$ is on the order of magnitude of the sediment grain size $D$.

New flume experiments, data from the literature and a semi-empirical investigation of antidune wavelength will provide the analysis. First, a set of dimensionless parameters are deduced from a dimensional analysis. Second, these parameters are used with new steep slope flume experiments (19 runs) to fit a relation giving the antidune wavelength. Third, the model is tested with data from the literature (148 runs) and is compared to existing models. To finish, the results are discussed.

\section{MODELLING}

\section{Dimensional analyses}

To identify the relevant scaling parameters, we used the dimensional analysis method, which assumes minimal a priori knowledge of antidune dynamics. For the sake of brevity and 
clarity, we restricted the analysis to two-dimensional bedforms (also called long-crested

104 antidunes).

106 The antidune wavelength $L$ can be expressed as a function of nine variables, as represented 107 symbolically by:

$$
L=f_{1}\left(A, R_{b}, U, S, v, \rho, \rho_{s}, g, D\right)
$$

108 where $A$ is the antidune amplitude, $R_{b}$ is the bed's hydraulic radius (obtained after side wall

109 correction of the measured hydraulic radius $R=h W /[2 h+W]$, where $h$ is the flow depth and $W$

110 is the flow width), $U$ is the mean flow velocity, $S$ is the energy slope, $v$ is the water viscosity,

$111 \rho$ is the water density, $\rho_{s}$ is the sediment density, $g$ is the acceleration of gravity and $D$ is the

112 grain diameter. Using the Buckinghams's pi theorem, ten variables involving three basic

113 dimensions would give seven dimensionless pi terms and Eq. 2 could be reduced to:

$$
\frac{L}{D}=f_{2}\left(F, \operatorname{Re}, \operatorname{Re}^{*}, \frac{R_{b}}{D}, S, s\right)
$$

114 Where $F=U /(g h)^{0.5}$ is the Froude number, $R e=U h / v$ is the Reynolds number, $R e^{*}=u^{*} D / v$ is

115 the grain Reynolds number (where $u^{*}=(g R S)^{0.5}=(\tau \rho)^{0.5}$ is the shear velocity), $R_{b} / D$ is the

116 relative depth and $s=\rho_{s} / \rho$ is the relative sediment density. Since flows on steep slopes are 117 rough $\left(R e^{*>70)}\right.$ and turbulent $(R e>2000), R e$ and $R e^{*}$ can be neglected (both for flow 118 resistance and bedload transport).

120 In Figure 3 antidunes appear with sediment transport and wavelength increases as flow 121 conditions increase (characterized by the $\theta / \theta_{c}$ ratio), with amplitude remaining almost 122 constant (on the order of magnitude of the grain diameter) until the antidunes completely 123 disappears when $\theta=2.5 \theta_{c}$ approximately. For this reason, we suggest looking for a relation 124 linking the antidune geometry to the Shields ratio $\theta / \theta_{c}$. The relative depth $R_{b} / D$, the relative 
density $s$ and the slope $S$ can be rearranged to form the Shields number (Eq. 1). The method used in this study is original in that instead of using a constant critical Shields stress $\theta_{c}$ we

127 propose using a variation of this parameter with slope in reference to Lamb et al [2008] and 128 Recking [2009] (this choice will be considered further in the discussion). The following

129 slope-dependent equation proposed in Recking et al [2008b] is used:

$$
\theta_{c}=0.15 S^{0.275}
$$

130 Finally, considering a natural sediment mixture ( $\rho_{s} / \rho$ constant and equal to 2.65$)$, Eq. 3 can be 131 written:

$$
\frac{L}{D}=f_{3}\left(\theta, \theta_{c}, F\right)
$$

\section{Experiments}

134 New experiments were conducted at Cemagref to investigate Eq. 5. The experimental setup was a 6-m-long flume. The flume width was varied between 0.05 and $0.102 \mathrm{~m}$. We used three uniform sediments $-2.3 \mathrm{~mm}, 9 \mathrm{~mm}$ and $23 \mathrm{~mm}$ in diameter - and we varied the slope from 3

137 to $12.6 \%$. The flow rate at the inlet was ensured by a constant head reservoir and measured by

138 an electromagnetic flowmeter. Before each experiment (for a given material and a given

139 slope), we systematically measured the bed infiltration rate (part of the flow discharge

140 flowing within the gravel bed), which was deduced from the total inlet flow discharge. The

141 sediment feeding system consisted of a customized conveyor belt device ensuring constant

142 feeding (see Recking et al [2008a] for further detail). For each run, measurements were made

143 only after attaining a dynamic equilibrium condition, i.e. near-equality of the feed and trap

144 sediment transport rates, and a near constant time-averaged bed slope. Train antidunes were

145 usually instable and observed over finite distances (generally not affecting the entire flume

146 length). The wavelength $L$ was measured by dividing this distance by the number of 
147 antidunes. Antidune height was difficult to measure precisely. The flow velocity and the flow

148 depth were deduced from the flow discharge $Q$ using the following friction equation for rough

149 turbulent flows, based on the analysis of 2282 flume and field flow resistance values

150 [Recking, et al., 2008b]:

$$
\frac{U}{\sqrt{g R_{b} S}}=6.25+5.75 \log \left(\frac{R_{b}}{\alpha_{R L} \alpha_{B R} D}\right)
$$

151 where $U$ is the vertically averaged flow velocity and

$$
\begin{aligned}
& \alpha_{R L}=4\left(\frac{R_{b}}{D}\right)^{-0.43} \text { with } 1 \leq \alpha_{R L} \leq 3.5 \\
& \alpha_{B R}=7 S^{0.85} \frac{R_{b}}{D} \text { with } 1<\alpha_{B R} \leq 2.6
\end{aligned}
$$

152 where $\alpha_{R L}$ is a roughness layer coefficient taking into account deviation from the logarithmic

153 profile on small relative depth flows (with an increasing influence of the roughness layer) and

$154 \alpha_{B R}$ is a bedload roughness coefficient taking into account additional flow resistance caused 155 by bedload. This flow resistance equation was derived for flat beds but proved to be valid for 156 flows with nonbreaking wave antidunes. The corresponding wavelength and flow conditions

157 are summarized in Table 1. $\Phi$ is the dimensionless solid discharge [Einstein, 1950] defined 158 by:

$$
\Phi=\frac{q_{s v}}{\sqrt{(s-1) g D^{3}}}
$$

159 Where $q_{s v}\left[\mathrm{~m}^{3} / \mathrm{s} / \mathrm{m}\right]$ is the volumetric transport rate per unit width.

\section{Model fitting}

162 A functional relationship between $L / D, \theta, \theta_{c}$ and $F$ is sought. The model will be investigated 163 in its simplest form, through a power equation: 


$$
\frac{L}{D}=\xi \theta^{\alpha} \theta_{c}^{\beta} F^{\gamma}
$$

164 where $\xi, \alpha, \beta$ and $\gamma$ are constant values to be fitted from our experimental results. The best fit

165 of Eq. $9\left(\mathrm{R}^{2}=0.99\right)$ gave the following equation (Figure 4$)$ :

$$
\frac{L}{D}=0.093 \frac{\theta}{\theta_{c}^{3}} F
$$

166 These coefficients allowed us to minimize to zero the mean error $\bar{\varepsilon}$ (where $\varepsilon$ is the difference

167 between the measured and calculated values of $L$ ) with a standard deviation $\sigma_{\varepsilon}=0.02$.

169 When rearranged with Eq. 1 and Eq.4, it was possible to eliminate $D$ from both sides, and

170 considering a natural sediment of relative density $s=2.65$, this equation could be reduced to:

$$
\frac{L}{R_{b}}=16 S^{0.17} F
$$

171 Similar equations could have been investigated for the antidune amplitude $A$, but

172 unfortunately, we did not produce enough data to investigate this parameter.

173

\section{MODEL VALIDATION AND COMPARISON}

175 In this section, we test the models' ability to reproduce measured wavelengths $L$ with 176 available data from the literature.

The data set

179 We built a data set composed of 148 values from Kennedy [1960], Simons and Richardson 180 [1966], Shaw and Kellerhals [1977], Cao [1985] and Recking [2006], obtained in flume 181 experiments with near uniform sediments. The data from Recking [2006] were produced in a

182 10-m-long, 0.1-m-wide flume in the Lyon LMFA laboratory (Laboratoire de Mécanique des 183 Fluides et d'Acoustique) and must be distinguished from the new data produced at Cemagref. 
184 For these runs, the flow velocity was not computed but measured with a marker technique

185 similar to the salt dilution technique (see Recking [2006] for further detail). Only a few field

186 values are available from Kennedy [1960]. However, the slope values were missing and, 187 given the fine grain diameter (approximately $0.3 \mathrm{~mm}$ ), a 0.001 slope was used for the 188 calculations. Actually the exact slope value is not very important because with a slope 189 exponent equal to 0.17 , the model distinguishes between gentle and steep slopes. For all runs, $190 R_{b}$ was calculated with the measured flow depths, after correction for side wall effects using 191 the procedure proposed by Johnson [1942] and modified by Vanoni and Brooks [1957]. The 192 data set is presented in Table 1 and indicates that antidunes on steep slopes were obtained in 193 the $1.1<\theta / \theta_{\mathrm{c}}<2.5$ range, whereas on gentle slopes antidunes were obtained in the $10<\theta / \theta_{\mathrm{c}}$ $194<90$ range.

196 The data set was compared to the commonly admitted domain permitting antidunes. These 197 limits were derived analytically and give the minimum Froude number $F_{m}$ [Kennedy, 1960] 198 and the maximum Froude number $F_{M}$ [Parker, 1975; Reynolds, 1965] for the formation of 199 antidunes for a given wave number $k=2 \pi / L$ and flow depth $h$ :

$$
\begin{aligned}
& F_{m}{ }^{2}=\frac{\tanh k h}{k h} \\
& F_{M}{ }^{2}=\frac{1}{k h \tanh k h}
\end{aligned}
$$

200 These equations were compared to the data set in Figure 5 and gave a good estimate of the 201 flow domain permitting antidunes, whatever the slope. Note that antidunes can also appear for 202 a Froude number as low as 0.8 . 
207 Figure 6 presents a comparison between the measured wavelengths and the wavelengths 208 computed with Eq. 11. The widely used wavelength equation proposed by Kennedy [1960] 209 was also used for the comparison (Figure 7):

$$
F^{2}=\frac{1}{k h}
$$

210 Models' efficincy was tested by calculating a relative root mean square error (RRMSE) 211 defined by:

$$
R R M S E=\frac{\sqrt{\bar{\varepsilon}^{2}+\sigma_{\varepsilon}^{2}}}{\overline{L_{m e s}}}
$$

212 where $\varepsilon$ is the error calculated from the difference between the measured and calculated 213 values of $L$ and $\sigma_{\varepsilon}$ is the standard deviation of $\varepsilon$. The results are presented in Table 3 . The 214 new model improves antidune wavelength prediction on steep slopes, but also on gentle 215 slopes. Figure 8 presents the calculated to measured ratios for each model and for increasing 216 slopes. As in a few cases the calculation error associated with Eq. 14 was very large, it was 217 necessary to remove these outliers in order to calculate average values that were truly 218 representative of the data set. The new model gives results to within $\pm 10 \%$ for all slope 219 values. The bad score on the 3\% slope corresponds to six data from Shaw and Kellerhals 220 [1977] (antidunes were obtained during a bed erosion experiment with no sediment feeding). 221 The model from Kennedy (Eqs. 14) gave similar results with an overestimation on gentle 222 slopes and a progressive decrease of the prediction ratio with increasing slope.

224 Because in field applications the available parameters may not be the flow depth $h$ but the 225 flow discharge $Q$, Eq. 11 was also tested by replacing measured $R_{b}$ and $F$ with values 226 calculated from the flow discharge $Q$, using Eq. 6 (the algorithm presented in Recking [2006] 227 takes into account a flume side wall effect). Wavelength prediction was unchanged for steep 
slope experiments $(\mathrm{RRMSE}=0.25)$. The results were not as good for gentle slope experiments

229 (Kennedy [1960] and Simons and Richardson [1966]) because they were associated with smooth and transitional flows $\left(R e^{*<70}\right)$ for which Eq. 6 is no longer appropriate.

\section{DISCUSSION}

\section{Physical significance}

234 Kennedy's equation (Eq.14) was based on the celerity equation for small-amplitude waves [Milne-Thomson, 1960] hypothesizing that flows can deform the boundary to conform to a streamline of a wave in a flow of infinite depth. It considers that for a given Froude number F, only one combination is possible between the flow depth $h$ and the bed deformation $L$. Doing so, it implicitly considers that processes controlling the flow resistance and bed load transport are unchanged whatever the slope. However recent studies have demonstrated that both the mean flow resistance and bedload transport were strongly affected by changing flow 241 hydraulics with changing slope:

242 (i) First, all the available flume and field data confirmed an increasing critical Shields 243 stress with increasing slope when plotted together [Recking, 2009]. This result was first 244 formulated by Shields himself (Shields [1936], pp. 16-17) and was confirmed by several 245 authors after him [Aksoy, 1973; Armanini and Gregoretti, 2005; Bathurst, 1987; Bathurst, et 246 al., 1982b; Bettess, 1984; Bogardi, 1970; Graf and Suszka, 1987; Mueller, et al., 2005; 247 Shvidchenko and Pender, 2000; Shvidchenko, et al., 2001; Tabata and Ichinose, 1971; 248 Tsujimoto, 1991; Vollmer and Kleinhans, 2007]. This variation with slope is not as would be 249 expected when studying the gravitational effects acting on the grain alone and several 250 explanations were given for this. Shields considered it was the result of a change in cross251 section when the relative depth decreased, whereas others believed it was the consequence of 252 the drag shear stress calculation in presence of form drag at low relative depth [Buffington 
and Montgomery, 1997]. However this finding was also confirmed for flows over fine gravels and without bedforms [Recking, 2008] which argues for another explanation. Recent analyses considered that gravitational effects acting on the grains are balanced by near bed flow velocity and turbulence changes with changing slope [Lamb, et al., 2008; Recking, 2009]. Even though the origin of this variation could appear controversial, the critical Shield stress increase with increasing slope is considered here, with several consequences observed not only on bedload transport, but also on flow resistance, as recalled hereafter.

(ii) The resulting critical Shields stress function $\theta_{c}(S)$ improved bedload prediction quite significantly in Recking et al [2008b] when the calculations were based on the concept of excess shear stress (i.e. as $\left.\Phi=f\left[\theta-\theta_{c}(S)\right]\right)$.

(iii) We also found that bedload strongly impacts flow resistance [Recking, et al., 2008a]. With the findings reviewed above, this explains why a slope-dependent roughness parameter $k_{s}(S)$ proved to greatly improve mean flow velocity prediction when used in the logarithmic flow resistance equations for $U / u^{*}$ (Eqs. 6 and 8).

These studies produced slope-dependent $\theta_{\mathrm{c}}(S), \Phi(S)$ and $U / u^{*}(S)$ functions as a consequence of the deviation from the law of the wall on steep slopes and because of flow resistance and bedload interactions. Thus, by impacting all parameters controlling antidunes when the slope is increased, these effects explain why antidune prediction was improved by incorporating the slope in the wavelength equation, through $\theta_{\mathrm{c}}(S)$. In addition, the good score obtained with Eq. 11 for any slope value may result from the fitting of the $\theta_{\mathrm{c}}(S)$ function (Eq.4) on the full range of slopes (from 0.001 to 0.1 ) in Recking [2008b].

Because it is not the gravitational effects associated with the changing slope that are responsible for the observed changes in antidune geometry but the changing flow hydraulics 
associated with changing slope, Eq. 11 can be rewritten as a function of the friction 278 coefficient considering $S=\left(U / u^{*}\right)^{-2} \mathrm{~F}^{2}$ (where $U / u^{*}=(8 / f)^{0.5}$ is the Darcy Weisbach coefficient):

$$
\frac{L}{R_{b}}=16 F^{1.35}\left(U / u^{*}\right)^{-0.35}
$$

279 This equation provides information on the wavelengths in the F-kh plane for a given value of $280 U / u^{*}$ (Figure 9). A complete physically based investigation would consist in deriving new 281 theoretical solutions incorporating these findings, but this was not the purpose of this paper.

\section{Antidune amplitude}

In Figure 3 antidunes appear with sediment transport and the bed is flattened when the flow condition increases. Table 4 presents the corresponding flow conditions and associated theoretical wavelengths as predicted with Eq.11. It indicates that when $\theta=2.5 \theta_{c}$ the wavelength should be $26 \mathrm{~cm}$. The flume length captured by images was approximately $20 \mathrm{~cm}$.

This suggests that for such high flow conditions antidunes were still presents, but because of the low amplitude (approximately one grain diameter height) and because the short observation window, they could not be observed. Instead, the bed appears flat.

292 Given that antidunes were produced with a very wide range of flume widths $(0.05-3.2 \mathrm{~m})$, 293 another question concerns the effect of flume geometry on antidune geometry (characterized 294 by an amplitude:wavelength ratio). Given that antidune amplitude data are rare, we also used 295 newly produced data to analyse the flume width effect. Figure 10 presents antidune amplitude 296 as a function of the wavelength. The first observation is that antidune geometries measured in 297 our 0.1-m-wide flume are very coherent with the antidune geometries measured by Cao in a 298 0.6-m-wide flume. These steep slope antidunes fit the following equation fairly well $299 \quad\left(\mathrm{R}^{2}=0.97\right)$ : 


$$
A=0.033 L
$$

300 Antidune geometries measured on gentle slopes in a 2.5-m-wide flume experiment by Simons 301 and Richardson [1966] are also coherent with this result despite a wider scatter. This suggests 302 that the flume width had no or little effect on antidune geometry. These aspects should be 303 evaluated through new experiments in a future investigation.

\section{Field implications}

306 The relevance of this research to field problems deserves discussion. Figure 2 presents 307 antidunes observed on a 3\% slope gravel bed river (the Arveyon River in Chamonix, France). 308 Successive trains of antidunes with a wavelength of approximately $3 \mathrm{~m}$ were regularly 309 produced at the same place and migrated upstream very quickly over a distance of approximately $50 \mathrm{~m}$, before disappearing. However, this observation is rare under field conditions. First, it appears to be rare to find supercritical flow conditions for long time periods and long reaches (e.g. Grant [1997]; it may be more typical to observe longitudinal alternation of supercritical and subcritical flows [Comiti and Lenzi, 2006]. Moreover, if on

314 some occasions antidunes can be observed after flooding [Foley, 1975], antidunes are usually 315 destroyed on falling water stages [Carling, 1999], which renders field observations very rare and comparisons difficult. The model fitted the few values presented by Kennedy [1960] in 317 Figure 6 fairly well.

Another important aspect concerns the effect of grain size distribution given that all the experiments presented in this paper were conducted with uniform or near uniform sediments, whereas natural sediments are usually poorly sorted. Smart and Jaeggi [1983] also obtained flat beds with their uniform sediments at high flow intensities (as was illustrated in Figure 3), but they obtained antidunes with nonuniform bed material in these flows. They did not 
provide wavelength values but they described "weak" antidunes. We suspect that such weak

325 antidunes did also exist in our experiments (see discussion above), but could not be observed.

326 We did not succeed in isolating the hydraulic specificities that could explain any differences

327 using Smart [1983]'s data. However, it was demonstrated that in presence of grain sorting,

328 hydraulics alone could not reproduce all phenomena associated with sediment transport

329 [Dietrich, et al., 1989; Iseya and Ikeda, 1987; Recking, 2006] and additional sediment mixture

330 properties are likely needed to fully understand antidunes in poorly sorted sediments.

\section{CONCLUSION}

333 This study intended to investigate antidune characteristics on steep slopes and to compare the

334 results with available results previously obtained on gentle slopes. Using a data set 335 comprising 167 values (19 newly produced data and 148 data from the literature) it was 336 shown that Kennedy's theoretical model for the dominant wavelength (Eq. 14) provided a 337 good estimation of measured wavelength, but with decreased efficiency (under prediction) as 338 slope increased.

340 A wavelength model based on dimensional analysis and new steep slope experiments was 341 proposed. This model proved to reproduce adequately steep slope data from the literature, but 342 also, to improve wavelength prediction on gentle slopes when compared to Kennedy's 343 models. This model incorporates parameters that are similar to previous ones, i.e. the Froude 344 number and the flow depth, but it also takes into account the changes in flow hydraulics 345 through a slope parameter as was demonstrated in Recking [2009]. The available data did not 346 permit to make any definitive conclusion on antidunes' amplitude. 
348 Additional steep slope data are needed to confirm these results. The grain sorting effects on 349 antidune geometry should also be investigated further because all the available data were 350 obtained with uniform sediments only. Only long-crested antidunes were considered. Three351 dimensional antidunes are expected to have shorter wavelengths than those reported in this 352 paper [Kennedy, 1963]. 


\section{ACKNOWLEDGMENTS}

354

355 This study was supported by Cemagref and funding was provided by the ECCO-PNRH 356 program from ANR/INSU $\mathrm{N}^{\mathrm{o}}$. ANR-05-ECCO-015, and the PGRN (Pole Grenoblois des 357 Risques Naturels). We are grateful to the TSI laboratory of Saint Etienne (Christophe 358 Ducottet, Nathalie Bochard, Jacques Jay, and Jean-Paul Schon).

359

360 The authors would like to thank Dieter Rickenmann and two other anonymous reviewers who

361 greatly contributed to this paper by providing helpful reviews of an earlier version of this 362 manuscript. Our thanks are extended to Rob Ferguson (Associate Editor) who greatly 363 contributed to this paper by providing additional reviews. 
366 Aksoy, S. (1973), The influence of relative depth on threshoàld of grain motion, paper 367 presented at IAHR, Bangkok, Thailand.

368 Armanini, A., and C. Gregoretti (2005), Incipient sediment motion at high slopes in uniform

369 flow condition, Water Resources Research, 41, 1-8.

370 Bathurst, J. C. (1987), Critical conditions for bed material movement in steep, boulder-bed

371 streams, paper presented at Erosion and Sedimentation in the Pacific Rim, AIHS Pub. $\mathrm{N}^{\circ} 165$,

372 Proceedings of the Corvallis Symposium.

373 Bathurst, J. C., W. H. Graf, and H. H. Cao (1982a), Bedforms and flow resistance in steep

374 gravel-bed channels, paper presented at Euromech 156 : Mechanism of sediment transport,

375 Istanbul.

376 Bathurst, J. C., W. H. Graf, and H. H. Cao (1982b), Initiation of sediment transport in steep

377 channels with coarse bed material, paper presented at Euromech 156: Mechanics of sediment 378 transport, Istanbul.

379 Bettess, R. (1984), Initiation of sediment transport in gravel streams, Proc., Institute of the 380 Civil Engineering, 77, Part 2, March, 79-88.

381 Bogardi, J. (1970), Sediment transportation in alluvial streams (International Post-Graduate

382 Course on Hydrological methods for developping water resources management), $\mathrm{N}^{\circ} 13$, 383 lecture notes, Subject 12, Research Institute for Water Research Development / UNESCO, 384 Budapest, Hungary, 133 pp

385 Buffington, J. M., and D. R. Montgomery (1997), A systematic analysis of eight decades of 386 incipient motion studies, with special reference to gravel-bedded rivers, Water Resources 387 Research, 33, 1993-2027.

388 Cao, H. H. (1985), Resistance hydraulique d'un lit à gravier mobile à pente raide; étude 389 expérimentale, $\mathrm{PhD}$ thesis thesis, 285 pp, Ecole Polytechnique Federale de Lausane, 390 Lausanne. 
Carling, P. A. (1999), Subaqueous gravel dunes, Journal of sedimentary research, 69, 534545.

393 Carling, P. A., and A. B. Shvidchenko (2002), The antidune transition in fine gravel with 394 especial consideration of downstream migrating antidunes. Sedimentology, Sedimentology, $39549,1269-1282$.

396 Chin, A. (1999), On the origin of step-pool sequences in mountain streams, Geophysical 397 research letters, 26, 231-234.

398 Colombini, M. (2004), Revisiting the linear theory of sand dune formation, Journal of Fluids 399 mechanics, 502, 1-16.

400 Colombini, M., and A. Stocchino (2005), Coupling and decoupling bed and flow dynamics:

401 fast and slow sediment waves at high Froude numbers, Physics of Fluids, 17.

402 Colombini, M., and A. Stocchino (2008), Finite-amplitude river dunes, Journal of Fluids 403 mechanics, 611, 283-306.

404 Comiti, F., and M. Lenzi (2006), Dimensions of standing waves at steps in moutain rivers, 405 Water Resources Research, 42, 1-13.

406 Curran, J. C. (2007), Step-pool formation models and associated step spacing, Earth Surface 407 Processes and Landforms, 32, 1611-1627.

408 Deigaard, R. (2008), Breaking antidunes: cyclic behavior due to hysteresis, Journal of 409 Hydraulic Engineering, 132, 620-623.

410 Dietrich, W. E., J. W. Kirchner, H. Ikeda, and F. Iseya (1989), Sediment supply and the 411 development of the coarse surface layer in gravel-bedded rivers, Nature, 340, 215-217.

412 Einstein, H. A. (1950), The bed-load function for sediment transportation in open channel 413 flows, Technical Bulletin $N^{\circ} 1026$, United States Department of Agriculture - Soil 414 Conservation Service, Washington, $71 \mathrm{pp}$ 
415 Engelund, F. (1970), Instability of erodible beds, Journal of Fluids mechanics (Digital 416 Archive), 42, 225-244.

417 Engelund, F., and E. Hansen (1967), A monograph on sediment transport in alluvial streams, 418 T. Forlag, Technical University of Denmark, $62 \mathrm{pp}$

419 Foley, M. G. (1975), Scour and fill in an ephemeral stream, D. o. G. a. P. Sciences, 420 Contribution $N^{\circ} 2658$, California institute of Technology, Pasadena

421 Gilbert, G. K. (1914), The Transportation of Debris by Running Water, Professional paper $422 \quad N^{\circ} 86$, US Geological Survey, Washington Government Printing Office, 263 pp

423 Graf, W. H., and L. Suszka (1987), Sediment transport in steep channels, Journal of 424 Hydrosciences and Hydraulic Engineering, 5, 11-26.

425 Grant, G. E. (1997), Critical flow constrains flow hydraulics in mobile-bed streams: A new 426 hypothesis, Water Resources Research, 33, 349-358.

427 Hayashi, T. (1970), Formation of dunes and antidunes in open channels, Journal of the 428 Hydraulics Division, HY2, 357-366.

429 Hayashi, T., and M. Onishi (1983), Dominant wave numbers of ripples, dunes and antidunes 430 on alluvial river beds, paper presented at Second International Symposium on River 431 Sedimentation, Nanjing, China.

432 Huang, L.-H., and Y.-L. Chiang (2001), The formation of dunes, antidunes and rapidly

433 damping waves in alluvial channels, Int. J. Numer. Anal. Meth. Geomech., 25, 675-690.

434 Iseya, F., and H. Ikeda (1987), Pulsations in bedload transport rates induced by a longitudinal 435 sediment sorting: a flume study using sand and gravel mixture, Geografiska Annaler, 69A, 1543627.

437 Johnson, J. W. (1942), The importance of side-wall friction in bed-load investigations, Civil 438 Eng., 12, 329-331. 
439 Kennedy, J. F. (1960), Stationary waves and antidunes in alluvial channels, 172 pp, PhD

440 Thesis, Califonia Institute of Technology, Pasadena, California.

441 Kennedy, J. F. (1963), The mechanics of dunes and antidunes in erodible-bed channels,

442 Journal of Fluids mechanics (Digital Archive), 16, 521-544.

443 Kubo, Y., and M. Yokokawa (2001), Theoretical study on breaking of waves on antidunes,

444 Spec. Publs. int. ass. sediment, 31, 65-70.

445 Lamb, M. P., W. E. Dietrich, and J.-G. venditti (2008), Is the critical Shields stress for

446 incipient sediment motion dependent on channel-bed slope?, J. Geophys. Res., 113.

447 Lenzi, M. A. (2001), Step-pool evolution in the rio Cordon, northeastern Italy, Earth Surface

448 Processes and Landforms, 26, 991-1008.

449 Milne-Thomson, J. H. (1960), Theretical hydrodynamics, New-York.

450 Mueller, E. R., J. Pitlick, and J. M. Nelson (2005), Variation in the reference Shields stress for 451 bed load transport in gravel-bed streams and rivers, Water Resources Research, 41, W04006 452 (04001-04010).

453 Parker, G. (1975), Sediment inertia as cause of river antidunes, Journal of the Hydraulics 454 Division, 101, 211-221.

455 Raudkivi, A. J. (1966), Bedforms in alluvial channels, Journal of Fluids mechanics (Digital 456 Archive), 26, 507-514.

457 Recking, A. (2006), An Experimental Study of Grain Sorting Effects on Bedload, 261 pp, 458 PhD Thesis Cemagref www.lyon.cemagref.fr/doc/these/recking/index.shtml, Lyon.

459 Recking, A. (2008), Variation du nombre de Shields critique avec la pente, La Houille 460 Blanche, 5, 59-63.

461 Recking, A. (2009), Theoretical development on the effects of changing flow hydraulics on 462 incipient bedload motion, Water Resources Research, 45, W04401, 16. 
Recking, A., P. Frey, A. Paquier, P. Belleudy, and J. Y. Champagne (2008a), Bedload transport flume experiments on steep slopes, Journal of Hydraulic Engineering, 134, 13021310.

Recking, A., P. Frey, A. Paquier, P. Belleudy, and J. Y. Champagne (2008b), Feedback

467 between bed load and flow resistance in gravel and cobble bed rivers, Water Resources

468 Research, 44, 21.

469 Reynolds, A. J. (1965), Waves on the erodible bed of an open channel, Journal of Fluids 470 mechanics, 22, 113-133.

471 Sammarco, P., C. C., M. Trulsen, and K. Trulsen (2006), Nonlinear resonance of free surface 472 waves in a current over a sinusoidal bottom: a numerical study, Journal of Fluid mechanics 473 (Digital Archive), 279.

474 Shaw, J., and R. Kellerhals (1977), Paleohydraulic interpretation of antidune bedforms with 475 applications to antidunes in gravel, Journal of Sedimentary Petrology, 47, 257-266.

476 Shields, A. (1936), Anwendung der Aehnlichkeitsmechanik und der Turbulenzforschung auf 477 die Geschiebebewegung, Mitteilungen der Preussischen Versuchsanstalt fur Wasserbau und 478 Schiffbau, 36 pp, (English Translation by WP Ott and JC Van Uchelen) USDA Soil 479 Conservation Service Cooperative Laboratory, California Institute of Technology, Pasadena, 480 Ca, Hydrodynamics Laboratory Publication $N^{\circ}$ 167, Berlin, Heft 26, 26.

481 Shvidchenko, A., and G. Pender (2000), Flume study of the effect of relative depth on the 482 incipient motion of coarse uniform sediments, Water Resources Research, 36, 619-628.

483 Shvidchenko, A., G. Pender, and T. B. Hoey (2001), Critical shear stress for incipient motion 484 of sand/gravel streambeds, Water Resources Research, 37, 2273.

485 Simons, D. B., and E. V. Richardson (1966), Resistance to flow in alluvial channels, 486 Geological Survey Professional Paper 462-J, Washington, 96 pp 
Smart, G. M., and M. N. R. Jaeggi (1983), Sediment transport on steep slopes, 89-191 pp.,

488 Mitteilungen $n^{\circ}$ 64, Der Versuchsanstalt fuer Wasserbau, Hydrologie und Glaziologie, Eidg.

489 Techn. Hochschule Zuerich, Zurich.

490 Tabata, S., and Y. Ichinose (1971), An Experimental Study on Critical Tractive Force of

491 Cobble Gravels, SHIN-SABO, Vol.23, No.4, Ser. No.79, 12-20.

492 Tsujimoto, T. (1991), Bed-load transport in steep channels, Fluvial Hydraulics of Mountain

493 Regions, Lect; Notes Earth Sci. ser., 37, 89-102.

494 Van Rijn, L. C. (1984), Sediment transport, Part III : Bed forms and alluvial roughness,

495 Journal of Hydraulic Engineering, 110, 1733-1755.

496 Vanoni, V. A., and N. H. Brooks (1957), Laboratory studies of the roughness and suspended

497 load of alluvial streams, Report $\mathrm{N}^{\circ} \mathrm{E}-68$, Sedimentation Laboratory, California Institute of

498 Technology, Passadena, California, $120 \mathrm{pp}$

499 Vollmer, S., and G. Kleinhans (2007), Predicting incipient motion, including the effect of

500 turbulence pressure fluctuations in the bed, Water Resources Research, 43, 1-16.

501 Weichert, R. B., G. R. Bezzola, and H.-E. Minor (2008), Bed morphology and generation of

502 step-pool channels, Earth Surface Processes and Landforms, 33, 1678-1692.

503 Whittaker, J. G., and M. Jaeggi (1982), Origin of step-pool systems in mountain streams, 504 Journal of the Hydraulics Division, 108, 758-773.

505

506 


\section{FIGURES CAPTION}

508 Figure 1: Schematic presentation of antidunes characterized by a sediment wave migration in

509 the upstream direction and a bed surface in phase with the form of the water surface.

510 Figure 2 : Antidunes on the Arveyron river, a 3\% slope gravel bed river in Chamonix

511 (France). The wavelength was approximately $2 \mathrm{~m}$.

Figure 3: Images of antidunes for increasing flow conditions characterized by the ratio $\theta / \theta_{\mathrm{c}}$.

515 Each image presents the free surface and the moving grains.

Figure 4: Wavelength model fitting

Figure 5: Comparison between equations and available antidune data

520

521

522

523

524

525

526

527

Figure 6: Comparison between computed (with Eq. 11) and measured wavelengths (77\% of the values are within the envelop $\pm 20 \%$ )

Figure 7: Comparison between computed (with Eq. 14) and measured wavelengths (51\% of the values are within the envelope $\pm 20 \%$ )

Figure 8: Calculated-to-measured wavelength ratio for each model and different slopes (each point represents a slope range, from left to right: $S<0.005-0.007-0.01-0.03-0.05-0.07-$ 0.09 - 0.12). Vertical lines represent the standard deviation.

Figure 9 : Wavelengths in the F-kh plane with consideration of $U / \mathrm{u}^{*}$ values

Figure 10: Amplitude versus wavelength 


\begin{tabular}{|c|c|c|c|c|c|c|c|c|c|c|c|c|c|c|c|c|}
\hline Run & $\begin{array}{c}W \\
(\mathrm{~m})\end{array}$ & $\begin{array}{c}D \\
(\mathrm{~mm})\end{array}$ & $S$ & $\begin{array}{c}Q \\
(1 / \mathrm{s})\end{array}$ & $\underset{(\mathrm{m} / \mathrm{s})}{U}$ & $\begin{array}{c}h \\
(\mathrm{~cm})\end{array}$ & $\mathrm{Rb} / \mathrm{D}$ & $\mathrm{U} / \mathrm{u}^{*} \mathrm{C}$ & $\mathrm{F}$ & $\operatorname{Re}$ & $\operatorname{Re}^{\star}$ & $\theta$ & $\theta / \theta_{\mathrm{c}}$ & $\phi$ & $\begin{array}{c}L \\
(\mathrm{~m})\end{array}$ & $\begin{array}{c}A \\
(\mathrm{~m})\end{array}$ \\
\hline 1 & 0.05 & 2.3 & 0.0300 & 0.24 & 0.40 & 1.20 & 4.66 & 7.12 & 1.17 & 4800 & 129 & 0.085 & 1.48 & $5.28 \mathrm{E}-03$ & 0.114 & \\
\hline 2 & 0.05 & 2.3 & 0.0300 & 0.28 & 0.42 & 1.33 & 5.14 & 7.12 & 1.16 & 5600 & 136 & 0.093 & 1.63 & 1.76E-02 & 0.143 & \\
\hline 3 & 0.05 & 2.3 & 0.0500 & 0.19 & 0.38 & 0.97 & 4.06 & 5.61 & 1.23 & 3700 & 154 & 0.120 & 1.87 & 6.34E-02 & 0.100 & \\
\hline 4 & 0.05 & 2.3 & 0.0700 & 0.13 & 0.31 & 0.84 & 3.51 & 4.16 & 1.08 & 2600 & 171 & 0.149 & 2.06 & 7.75E-02 & 0.095 & \\
\hline 5 & 0.05 & 2.3 & 0.0900 & 0.10 & 0.29 & 0.69 & 2.91 & 3.77 & 1.11 & 2000 & 177 & 0.159 & 2.05 & 4.05E-02 & 0.087 & \\
\hline 6 & 0.10 & 9 & 0.0516 & 1.50 & 0.61 & 2.41 & 2.56 & 5.65 & 1.26 & 14737 & 993 & 0.084 & 1.21 & 2.70E-03 & 0.295 & 0.015 \\
\hline 7 & 0.10 & 9 & 0.0516 & 2.00 & 0.67 & 2.91 & 3.08 & 5.66 & 1.26 & 19593 & 1093 & 0.101 & 1.45 & 1.34E-02 & 0.360 & 0.014 \\
\hline 8 & 0.10 & 9 & 0.0516 & 2.50 & 0.73 & 3.38 & 3.50 & 5.78 & 1.26 & 24512 & 1177 & 0.117 & 1.65 & 3.05E-02 & 0.399 & 0.015 \\
\hline 9 & 0.10 & 9 & 0.0516 & 3.00 & 0.77 & 3.82 & 3.96 & 5.74 & 1.26 & 29448 & 1252 & 0.133 & 1.86 & $5.24 \mathrm{E}-02$ & 0.431 & 0.011 \\
\hline 10 & 0.10 & 9 & 0.0853 & 1.00 & 0.51 & 1.94 & 2.11 & 4.05 & 1.16 & 9820 & 1146 & 0.111 & 1.43 & $1.59 \mathrm{E}-02$ & 0.243 & 0.014 \\
\hline 11 & 0.10 & 9 & 0.0853 & 1.30 & 0.55 & 2.31 & 2.53 & 3.98 & 1.16 & 12756 & 1250 & 0.132 & 1.72 & 4.28E-02 & 0.315 & 0.013 \\
\hline 12 & 0.10 & 9 & 0.0853 & 1.50 & 0.58 & 2.54 & 2.76 & 4.02 & 1.16 & 14709 & 1311 & 0.146 & 1.87 & 6.59E-02 & 0.349 & 0.013 \\
\hline 13 & 0.10 & 9 & 0.0853 & 1.70 & 0.60 & 2.76 & 3.02 & 3.98 & 1.16 & 16662 & 1367 & 0.158 & 2.05 & $9.25 \mathrm{E}-02$ & 0.350 & 0.013 \\
\hline 14 & 0.10 & 9 & 0.1260 & 0.87 & 0.43 & 1.98 & 2.21 & 2.74 & 0.98 & 8538 & 1406 & 0.168 & 1.99 & 1.01E-01 & 0.243 & 0.015 \\
\hline 15 & 0.10 & 9 & 0.1260 & 1.00 & 0.45 & 2.17 & 2.42 & 2.74 & 0.98 & 9813 & 1475 & 0.184 & 2.18 & 1.46E-01 & 0.237 & \\
\hline 16 & 0.10 & 9 & 0.1260 & 1.10 & 0.47 & 2.27 & 2.55 & 2.79 & 1.01 & 10780 & 1510 & 0.193 & 2.29 & 1.77E-01 & 0.274 & \\
\hline 17 & 0.10 & 23 & 0.1260 & 2.50 & 0.61 & 4.00 & 1.73 & 2.75 & 0.98 & 24528 & 5111 & 0.133 & 1.55 & 3.22E-02 & 0.446 & 0.022 \\
\hline 18 & 0.10 & 23 & 0.1260 & 2.70 & 0.63 & 4.21 & 1.80 & 2.78 & 0.98 & 26489 & 5245 & 0.140 & 1.62 & $4.22 \mathrm{E}-02$ & 0.465 & 0.017 \\
\hline 19 & 0.10 & 23 & 0.1260 & 3.00 & 0.65 & 4.51 & 1.94 & 2.77 & 0.98 & 29396 & 5433 & 0.150 & 1.75 & $6.04 \mathrm{E}-02$ & 0.555 & 0.022 \\
\hline
\end{tabular}




\begin{tabular}{|c|c|c|c|c|c|c|c|c|c|c|c|c|c|c|c|c|c|c|}
\hline $\mathrm{N}^{\circ}$ & Author & Ref & $\begin{array}{c}W \\
(\mathrm{~m})\end{array}$ & $\begin{array}{c}D \\
(\mathrm{~mm})\end{array}$ & $S$ & $\begin{array}{c}Q \\
(1 / \mathrm{s}) \\
\end{array}$ & $\begin{array}{c}U \\
(\mathrm{~m} / \mathrm{s})\end{array}$ & $h(\mathrm{~cm})$ & $R b / D$ & $U / u^{*}$ & $F$ & $\operatorname{Re}$ & $\mathrm{Re}^{*}$ & $\theta$ & $\theta / \theta_{c}$ & $\phi$ & $\begin{array}{c}L \\
(\mathrm{~m}) \\
\end{array}$ & $\begin{array}{c}A \\
(\mathrm{~m}) \\
\end{array}$ \\
\hline 1 & Recking & & 0.10 & 4.9 & 0.0300 & 1.40 & 0.57 & 2.46 & 4.57 & 7.02 & 1.16 & 9388 & 365 & 0.083 & 1.45 & $9.00 \mathrm{E}-03$ & 0.230 & \\
\hline 2 & Recking & & 0.10 & 4.9 & 0.0300 & 1.60 & 0.60 & 2.67 & 4.93 & 7.12 & 1.17 & 10435 & 379 & 0.090 & 1.57 & $1.60 \mathrm{E}-02$ & 0.240 & \\
\hline 3 & Recking & & 0.10 & 4.9 & 0.0500 & 0.70 & 0.47 & 1.49 & 2.90 & 5.63 & 1.23 & 5393 & 376 & 0.088 & 1.34 & $9.00 \mathrm{E}-03$ & 0.140 & \\
\hline 4 & Recking & & 0.10 & 4.9 & 0.0500 & 0.80 & 0.49 & 1.63 & 3.18 & 5.61 & 1.22 & 6031 & 393 & 0.096 & 1.46 & 1.60E-02 & 0.170 & \\
\hline 5 & Recking & & 0.10 & 4.9 & 0.0500 & 0.90 & 0.51 & 1.76 & 3.42 & 5.62 & 1.23 & 6652 & 408 & 0.104 & 1.58 & $2.50 \mathrm{E}-02$ & 0.190 & \\
\hline 6 & Recking & & 0.10 & 4.9 & 0.0500 & 1.05 & 0.53 & 1.98 & 3.83 & 5.52 & 1.20 & 7520 & 432 & 0.116 & 1.76 & $4.00 \mathrm{E}-02$ & 0.200 & \\
\hline 7 & Recking & & 0.10 & 4.9 & 0.0500 & 1.20 & 0.55 & 2.18 & 4.21 & 5.47 & 1.19 & 8354 & 452 & 0.127 & 1.94 & 5.70E-02 & 0.230 & \\
\hline 8 & Recking & & 0.10 & 4.9 & 0.0500 & 1.30 & 0.56 & 2.32 & 4.47 & 5.40 & 1.17 & 8878 & 466 & 0.135 & 2.06 & 6.90E-02 & 0.260 & \\
\hline 10 & Recking & & 0.10 & 4.9 & 0.0700 & 0.60 & 0.39 & 1.54 & 3.06 & 3.84 & 1.00 & 4588 & 456 & 0.130 & 1.80 & $3.40 \mathrm{E}-02$ & 0.150 & \\
\hline 11 & Recking & & 0.10 & 4.9 & 0.0700 & 0.70 & 0.44 & 1.59 & 3.15 & 4.28 & 1.11 & 5310 & 463 & 0.133 & 1.85 & 5.30E-02 & 0.180 & \\
\hline 12 & Recking & & 0.10 & 4.9 & 0.0700 & 0.80 & 0.46 & 1.74 & 3.43 & 4.28 & 1.11 & 5935 & 484 & 0.146 & 2.02 & 7.40E-02 & 0.190 & \\
\hline 13 & Recking & & 0.10 & 4.9 & 0.0700 & 0.90 & 0.49 & 1.84 & 3.61 & 4.44 & 1.15 & 6582 & 496 & 0.153 & 2.12 & $9.70 \mathrm{E}-02$ & 0.210 & \\
\hline 14 & Recking & & 0.10 & 9 & 0.0700 & 1.20 & 0.54 & 2.22 & 2.37 & 4.46 & 1.16 & 8308 & 1089 & 0.100 & 1.39 & 1.40E-02 & 0.260 & \\
\hline 15 & Recking & & 0.10 & 9 & 0.0700 & 1.40 & 0.56 & 2.50 & 2.66 & 4.37 & 1.13 & 9333 & 1153 & 0.113 & 1.56 & 2.60E-02 & 0.310 & \\
\hline 16 & Recking & & 0.10 & 9 & 0.0700 & 1.60 & 0.60 & 2.67 & 2.82 & 4.54 & 1.17 & 10435 & 1188 & 0.120 & 1.66 & 3.90E-02 & 0.360 & \\
\hline 17 & Recking & & 0.10 & 9 & 0.0700 & 1.90 & 0.61 & 3.11 & 3.29 & 4.28 & 1.10 & 11707 & 1284 & 0.140 & 1.93 & 6.30E-02 & 0.380 & \\
\hline 18 & Recking & & 0.10 & 9 & 0.0900 & 1.20 & 0.53 & 2.26 & 2.43 & 3.81 & 1.12 & 8260 & 1251 & 0.133 & 1.72 & 5.60E-02 & 0.260 & \\
\hline 20 & Recking & & 0.10 & 9 & 0.0900 & 1.70 & 0.59 & 2.91 & 3.08 & 3.77 & 1.10 & 10751 & 1414 & 0.169 & 2.17 & 1.28E-01 & 0.380 & \\
\hline 21 & Cao & 105 & 0.60 & 22.2 & 0.0300 & 60.00 & 1.14 & 8.78 & 3.80 & 7.24 & 1.23 & 77360 & 3499 & 0.069 & 1.21 & 3.26E-04 & 0.900 & 0.040 \\
\hline 22 & Cao & 106 & 0.60 & 22.2 & 0.0300 & 71.00 & 1.13 & 10.47 & 4.54 & 6.56 & 1.11 & 87715 & 3823 & 0.083 & 1.44 & 1.19E-03 & 1.135 & \\
\hline 23 & Cao & 107 & 0.60 & 22.2 & 0.0300 & 81.00 & 1.39 & 9.71 & 4.15 & 8.44 & 1.42 & 101984 & 3657 & 0.076 & 1.32 & $6.38 \mathrm{E}-03$ & 1.395 & \\
\hline 24 & Cao & 108 & 0.60 & 22.2 & 0.0300 & 92.00 & 1.40 & 10.95 & 4.68 & 8.01 & 1.35 & 112326 & 3882 & 0.085 & 1.49 & 1.12E-02 & 1.265 & \\
\hline 25 & Cao & 127 & 0.60 & 22.2 & 0.0300 & 100.00 & 1.25 & 13.33 & 5.74 & 6.45 & 1.09 & 115385 & 4300 & 0.104 & 1.83 & 2.05E-02 & 1.268 & \\
\hline 26 & Cao & 117 & 0.60 & 22.2 & 0.0500 & 35.00 & 1.00 & 5.85 & 2.57 & 5.98 & 1.32 & 48813 & 3721 & 0.078 & 1.18 & 1.34E-03 & 0.620 & \\
\hline 27 & Cao & 118 & 0.60 & 22.2 & 0.0500 & 40.00 & 0.93 & 7.14 & 3.17 & 5.01 & 1.12 & 53854 & 4114 & 0.096 & 1.46 & $6.00 \mathrm{E}-03$ & 0.740 & \\
\hline 28 & Cao & 123 & 0.60 & 22.2 & 0.0500 & 45.00 & 0.97 & 7.70 & 3.41 & 5.03 & 1.12 & 59681 & 4270 & 0.103 & 1.57 & 1.06E-02 & 0.725 & \\
\hline 29 & Cao & 119 & 0.60 & 22.2 & 0.0500 & 50.00 & 1.25 & 6.70 & 2.92 & 7.02 & 1.54 & 26300 & 3765 & 0.089 & 1.34 & $1.48 \mathrm{E}-02$ & 0.888 & \\
\hline 30 & $\mathrm{Cao}$ & 120 & 0.60 & 22.2 & 0.0500 & 60.00 & 1.38 & 7.20 & 3.16 & 7.45 & 1.64 & 28300 & 3808 & 0.096 & 1.45 & 2.85E-02 & 1.040 & 0.050 \\
\hline 31 & Cao & 121 & 0.60 & 22.2 & 0.0500 & 80.00 & 1.73 & 7.70 & 3.31 & 9.11 & 1.99 & 35500 & 3901 & 0.100 & 1.53 & 6.35E-02 & 1.115 & 0.045 \\
\hline 32 & Cao & 122 & 0.60 & 22.2 & 0.0500 & 100.00 & 2.00 & 8.30 & 3.54 & 10.18 & 2.22 & 41600 & 4085 & 0.107 & 1.63 & 1.03E-01 & 1.010 & 0.020 \\
\hline 33 & $\mathrm{Cao}$ & 130 & 0.60 & 22.2 & 0.0700 & 30.00 & 0.94 & 5.31 & 2.36 & 4.96 & 1.31 & 42483 & 4207 & 0.100 & 1.39 & 2.26E-02 & 0.677 & \\
\hline 34 & Cao & 131 & 0.60 & 22.2 & 0.0700 & 40.00 & 1.16 & 5.70 & 2.54 & 5.90 & 1.55 & 61300 & 4094 & 0.108 & 1.49 & 5.01E-02 & 0.800 & \\
\hline 35 & Cao & 132 & 0.60 & 22.2 & 0.0700 & 50.00 & 1.49 & 6.70 & 2.45 & 7.71 & 1.84 & 88800 & 4292 & 0.104 & 1.44 & 1.07E-01 & 0.880 & \\
\hline 36 & Cao & 133 & 0.60 & 22.2 & 0.0700 & 60.00 & 1.42 & 8.20 & 3.09 & 6.54 & 1.58 & 102000 & 4689 & 0.131 & 1.81 & 1.37E-01 & 0.897 & 0.040 \\
\hline 37 & Cao & 134 & 0.60 & 22.2 & 0.0700 & 70.00 & 1.42 & 8.22 & 3.60 & 6.06 & 1.58 & 91585 & 5203 & 0.153 & 2.12 & $1.40 \mathrm{E}-01$ & 0.863 & 0.030 \\
\hline 38 & Cao & 140 & 0.60 & 22.2 & 0.0900 & 40.00 & 0.87 & 7.70 & 3.41 & 3.36 & 1.00 & 53053 & 5756 & 0.187 & 2.41 & $9.69 \mathrm{E}-02$ & 0.715 & \\
\hline
\end{tabular}




\begin{tabular}{|c|c|c|c|c|c|c|c|c|c|c|c|c|c|c|c|c|c|c|}
\hline 39 & Cao & 141 & 0.60 & 22.2 & 0.0900 & 50.00 & 1.11 & 7.54 & 3.33 & 4.34 & 1.28 & 66593 & 5684 & 0.182 & 2.35 & $1.59 \mathrm{E}-01$ & 0.830 & \\
\hline 40 & Cao & 221 & 0.60 & 44.3 & 0.0300 & 150.00 & 1.53 & 16.30 & 3.47 & 7.19 & 1.21 & 161997 & 9415 & 0.063 & 1.10 & 1.15E-03 & 2.120 & \\
\hline 41 & Cao & 223 & 0.60 & 44.3 & 0.0300 & 170.00 & 1.64 & 17.29 & 3.65 & 7.52 & 1.26 & 179754 & 9667 & 0.066 & 1.16 & 1.56E-03 & 2.000 & \\
\hline 42 & Cao & 231 & 0.60 & 44.3 & 0.0500 & 90.00 & 1.37 & 10.99 & 2.39 & 6.01 & 1.31 & 109786 & 10114 & 0.073 & 1.10 & 1.10E-03 & 1.760 & \\
\hline 43 & Cao & 232 & 0.60 & 44.3 & 0.0500 & 110.00 & 1.49 & 12.31 & 2.67 & 6.18 & 1.35 & 129985 & 10683 & 0.081 & 1.23 & $1.01 \mathrm{E}-02$ & 1.800 & \\
\hline 44 & Cao & 233 & 0.60 & 44.3 & 0.0500 & 130.00 & 1.42 & 15.31 & 3.32 & 5.28 & 1.15 & 143449 & 11929 & 0.101 & 1.53 & 1.79E-02 & 2.250 & 0.078 \\
\hline 45 & Cao & 234 & 0.60 & 44.3 & 0.0500 & 150.00 & 1.65 & 15.19 & 3.27 & 6.19 & 1.35 & 165972 & 11830 & 0.099 & 1.51 & 3.19E-02 & 2.100 & 0.070 \\
\hline 46 & Cao & 238 & 0.60 & 44.3 & 0.0700 & 70.00 & 1.07 & 10.94 & 2.42 & 3.95 & 1.03 & 85482 & 12036 & 0.103 & 1.42 & 5.57E-03 & 1.180 & 0.050 \\
\hline 47 & Cao & 239 & 0.60 & 44.3 & 0.0700 & 90.00 & 1.24 & 12.15 & 2.67 & 4.35 & 1.13 & 106772 & 12653 & 0.114 & 1.57 & 2.42E-02 & 1.500 & 0.045 \\
\hline 48 & Cao & 240 & 0.60 & 44.3 & 0.0700 & 110.00 & 1.30 & 14.07 & 3.11 & 4.23 & 1.11 & 124801 & 13607 & 0.132 & 1.83 & 4.24E-02 & 1.800 & 0.060 \\
\hline 49 & Cao & 245 & 0.60 & 44.3 & 0.0900 & 70.00 & 1.04 & 11.24 & 2.50 & 3.33 & 0.99 & 84870 & 13857 & 0.136 & 1.76 & 3.30E-02 & 1.550 & 0.050 \\
\hline 50 & Cao & 246 & 0.60 & 44.3 & 0.0900 & 90.00 & 1.21 & 12.39 & 2.75 & 3.69 & 1.10 & 106166 & 14522 & 0.150 & 1.94 & 5.61E-02 & 2.000 & 0.070 \\
\hline 51 & Cao & 247 & 0.60 & 44.3 & 0.0900 & 110.00 & 1.37 & 13.41 & 2.96 & 4.03 & 1.19 & 126695 & 15086 & 0.162 & 2.09 & 8.80E-02 & 2.100 & 0.070 \\
\hline 52 & Cao & 322 & 0.60 & 11.5 & 0.0100 & 110.00 & 1.22 & 15.00 & 11.74 & 10.60 & 1.01 & 122215 & 1322 & 0.071 & 1.68 & $1.11 \mathrm{E}-02$ & 0.940 & \\
\hline 53 & Cao & 323 & 0.60 & 11.5 & 0.0100 & 130.00 & 1.31 & 16.56 & 12.76 & 10.92 & 1.03 & 139591 & 1381 & 0.077 & 1.83 & 1.89E-02 & 1.020 & \\
\hline 54 & Cao & 324 & 0.60 & 11.5 & 0.0100 & 150.00 & 1.42 & 17.66 & 13.38 & 11.56 & 1.08 & 157380 & 1415 & 0.081 & 1.92 & $2.72 \mathrm{E}-02$ & 1.200 & \\
\hline 55 & Kenned (flume) & 514 & 3.20 & 0.549 & 0.0272 & 170.07 & 1.42 & 3.75 & 67.45 & 14.29 & 2.34 & 53136 & 55 & 1.114 & 19.97 & $1.39 \mathrm{E}+01$ & 0.808 & \\
\hline 56 & Kenned (flume) & 52 & 3.20 & 0.549 & 0.0056 & 72.55 & 0.50 & 4.51 & 81.87 & 10.06 & 0.76 & 22687 & 27 & 0.276 & 7.71 & 2.78E-01 & 0.177 & \\
\hline 57 & Kenned (flume) & 510 & 3.20 & 0.549 & 0.0081 & 97.52 & 0.67 & 4.57 & 82.04 & 11.20 & 1.00 & 30519 & 33 & 0.404 & 10.10 & 8.47E-01 & 0.259 & \\
\hline 58 & Kenned (flume) & 57 & 3.20 & 0.549 & 0.0109 & 113.58 & 0.79 & 4.48 & 81.04 & 11.45 & 1.20 & 35508 & 38 & 0.534 & 12.37 & $1.82 \mathrm{E}+00$ & 0.305 & \\
\hline 59 & Kenned (flume) & 54 & 3.20 & 0.549 & 0.0125 & 122.20 & 0.84 & 4.57 & 82.02 & 11.30 & 1.25 & 38183 & 41 & 0.625 & 13.82 & $2.45 \mathrm{E}+00$ & 0.405 & \\
\hline 60 & Kenned (flume) & 59 & 3.20 & 0.549 & 0.0140 & 157.29 & 1.01 & 4.85 & 87.65 & 12.42 & 1.47 & 49189 & 45 & 0.740 & 16.04 & $3.73 E+00$ & 0.488 & \\
\hline 61 & Kenned (flume) & 517 & 3.20 & 0.549 & 0.0154 & 154.61 & 1.09 & 4.45 & 79.81 & 13.40 & 1.64 & 48287 & 45 & 0.748 & 15.65 & $3.73 E+00$ & 0.509 & \\
\hline 62 & Kenned (flume) & 58 & 3.20 & 0.549 & 0.0187 & 186.72 & 1.30 & 4.48 & 80.72 & 14.42 & 1.96 & 58314 & 49 & 0.914 & 18.22 & $7.87 \mathrm{E}+00$ & 0.655 & \\
\hline 63 & Kenned (flume) & 53 & 3.20 & 0.549 & 0.0055 & 158.77 & 0.66 & 7.47 & 135.15 & 10.43 & 0.78 & 49620 & 35 & 0.447 & 12.56 & $6.73 \mathrm{E}-01$ & 0.305 & \\
\hline 64 & Kenned (flume) & 55 & 3.20 & 0.549 & 0.0110 & 252.13 & 1.08 & 7.28 & 130.90 & 12.26 & 1.28 & 78824 & 48 & 0.871 & 20.11 & $4.08 \mathrm{E}+00$ & 0.610 & \\
\hline 65 & Kenned (flume) & 51 & 3.20 & 0.549 & 0.0067 & 265.51 & 0.79 & 10.55 & 188.57 & 9.58 & 0.77 & 82933 & 45 & 0.769 & 20.22 & $1.31 \mathrm{E}+00$ & 0.381 & \\
\hline 66 & Kenned (f) & 425 & 3.20 & 0.233 & 0.0032 & 73.14 & 0.48 & 4.79 & 201.73 & 12.50 & 0.70 & 22900 & 9 & 0.392 & 12.66 & 4.40E-01 & 0.183 & \\
\hline 67 & Kenned (f) & 437 & 3.20 & 0.233 & 0.0038 & 90.09 & 0.61 & 4.60 & 194.97 & 14.82 & 0.91 & 28197 & 10 & 0.447 & 13.86 & $1.74 \mathrm{E}+00$ & 0.259 & \\
\hline 68 & Kenned (flume) & 424 & 3.20 & 0.233 & 0.0048 & 98.71 & 0.69 & 4.48 & 188.90 & 15.16 & 1.04 & 30864 & 11 & 0.550 & 15.91 & $1.65 \mathrm{E}+00$ & 0.277 & \\
\hline 69 & Kenned (flume) & 429 & 3.20 & 0.233 & 0.0073 & 112.69 & 0.75 & 4.69 & 199.01 & 13.02 & 1.10 & 35195 & 13 & 0.881 & 22.71 & $6.87 \mathrm{E}+00$ & 0.363 & \\
\hline 70 & Kenned (flume) & 428 & 3.20 & 0.233 & 0.0066 & 112.09 & 0.78 & 4.51 & 189.99 & 14.57 & 1.17 & 35062 & 12 & 0.763 & 20.15 & $5.82 \mathrm{E}+00$ & 0.539 & \\
\hline 71 & Kenned (flume) & 426 & 3.20 & 0.233 & 0.0095 & 121.90 & 0.82 & 4.66 & 197.11 & 12.53 & 1.21 & 38094 & 15 & 1.139 & 27.23 & $1.10 \mathrm{E}+01$ & 0.482 & \\
\hline 72 & Kenned (flume) & 427 & 3.20 & 0.233 & 0.0160 & 148.66 & 1.00 & 4.63 & 197.40 & 11.77 & 1.49 & 46459 & 20 & 1.909 & 39.79 & $4.25 \mathrm{E}+01$ & 0.695 & \\
\hline 73 & Kenned (flume) & 436 & 3.20 & 0.233 & 0.0045 & 211.40 & 0.88 & 7.53 & 314.82 & 15.46 & 1.02 & 66088 & 13 & 0.861 & 25.30 & $8.19 E+00$ & 0.457 & \\
\hline 74 & Kenned (flume) & 433 & 3.20 & 0.233 & 0.0065 & 243.21 & 1.01 & 7.56 & 316.28 & 14.73 & 1.17 & 76032 & 16 & 1.251 & 33.18 & $1.97 \mathrm{E}+01$ & 0.600 & \\
\hline 75 & Kenned (flume) & 432 & 3.20 & 0.233 & 0.0094 & 263.43 & 1.04 & 7.89 & 334.27 & 12.27 & 1.18 & 82292 & 20 & 1.900 & 45.82 & $4.38 \mathrm{E}+01$ & 0.664 & \\
\hline 76 & Kenned (flume) & 412 & 0.85 & 0.233 & 0.0034 & 19.36 & 0.52 & 4.42 & 178.28 & 13.97 & 0.78 & 22766 & 9 & 0.371 & 11.69 & $2.94 \mathrm{E}-01$ & 0.183 & \\
\hline 77 & Kenned (flume) & 410 & 0.85 & 0.233 & 0.0042 & 25.44 & 0.64 & 4.69 & 189.00 & 15.02 & 0.94 & 29902 & 10 & 0.483 & 14.45 & $1.63 E+00$ & 0.274 & \\
\hline 78 & Kenned (flume) & 422 & 0.85 & 0.233 & 0.0068 & 30.73 & 0.80 & 4.51 & 183.44 & 14.98 & 1.21 & 36162 & 12 & 0.754 & 19.88 & $8.83 E+00$ & 0.454 & \\
\hline 79 & Kenned (flume) & 411 & 0.85 & 0.233 & 0.0082 & 32.00 & 0.84 & 4.51 & 182.74 & 14.35 & 1.26 & 37674 & 14 & 0.913 & 22.69 & $1.08 \mathrm{E}+01$ & 0.442 & \\
\hline
\end{tabular}




\begin{tabular}{|c|c|c|c|c|c|c|c|c|c|c|c|c|c|c|c|c|c|c|}
\hline 80 & Kenned (flume) & 417 & 0.85 & 0.233 & 0.0034 & 55.38 & 0.84 & 7.71 & 299.24 & 17.42 & 0.97 & 65107 & 11 & 0.613 & 19.62 & $6.13 \mathrm{E}+00$ & 0.509 & \\
\hline 81 & Kenned (flume) & 416 & 0.85 & 0.233 & 0.0071 & 70.08 & 1.05 & 7.83 & 311.17 & 14.78 & 1.20 & 82372 & 17 & 1.336 & 34.80 & $3.26 \mathrm{E}+01$ & 0.671 & \\
\hline 82 & Kenned (flume) & 413 & 0.85 & 0.233 & 0.0025 & 69.37 & 0.80 & 10.21 & 384.98 & 17.06 & 0.80 & 81541 & 11 & 0.584 & 20.20 & $3.48 \mathrm{E}+00$ & 0.430 & \\
\hline 83 & Kenned (flume) & 414 & 0.85 & 0.233 & 0.0032 & 94.01 & 1.04 & 10.61 & 391.12 & 19.44 & 1.02 & 110569 & 12 & 0.756 & 24.55 & $1.50 \mathrm{E}+01$ & 0.646 & \\
\hline 84 & Kennedy(Field) & 1 & & 0.157 & & & 0.76 & 7.01 & 446.50 & 28.98 & & 52992 & & & & & 0.381 & \\
\hline 85 & Kennedy(Field) & 2 & & 0.185 & & & 0.99 & 12.19 & 658.92 & 28.63 & & 120774 & & & & & 0.640 & \\
\hline 86 & Kennedy(Field) & 3 & & 0.45 & & & 0.98 & 5.49 & 122.00 & 42.23 & & 53512 & & & & & 0.457 & \\
\hline 87 & Kennedy(Field) & 4 & & 0.32 & & & 0.64 & 6.10 & 190.63 & 26.16 & & 39019 & & & & & 0.335 & \\
\hline 88 & Kennedy(Field) & 5 & & 0.41 & & & 1.16 & 14.33 & 349.51 & 30.94 & & 165925 & & & & & 0.792 & \\
\hline 89 & Kennedy(Field) & 6 & & 0.41 & & & 1.32 & 18.90 & 460.98 & 30.66 & & 248832 & & & & & 0.975 & \\
\hline 90 & Kennedy(Field) & 7 & & 0.38 & & & 1.49 & 24.38 & 641.58 & 30.47 & & 364180 & & & & & 1.219 & \\
\hline 91 & Kennedy(Field) & 8 & & 0.38 & & & 1.65 & 39.62 & 1042.63 & 26.47 & & 652179 & & & & & 2.164 & \\
\hline 92 & Kennedy(Field) & 9 & & 0.38 & & & 2.00 & 42.06 & 1106.84 & 31.14 & & 841033 & & & & & 3.353 & \\
\hline 93 & Kennedy(Field) & 10 & & 0.46 & & & 2.44 & 91.44 & 1987.83 & 25.76 & & 2229673 & & & & & 3.048 & \\
\hline 94 & Kennedy(Field) & 11 & & 0.41 & & & 1.98 & 94.49 & 2304.63 & 20.57 & & 1871996 & & & & & 4.572 & \\
\hline 95 & Kennedy(Field) & 12 & & 0.41 & & & 2.35 & 121.92 & 2973.66 & 21.49 & & 2861414 & & & & & 4.267 & \\
\hline 96 & Shaw & & 0.31 & 8 & 0.0250 & 13.00 & 0.78 & 5.50 & 6.38 & 6.97 & 1.06 & 31326 & 905 & 0.10 & 1.78 & & 0.372 & \\
\hline 97 & Shaw & & 0.31 & 8 & 0.0250 & 15.90 & 0.74 & 7.01 & 8.26 & 5.81 & 0.90 & 35719 & 1023 & 0.13 & 2.30 & & 0.390 & \\
\hline 98 & Shaw & & 0.31 & 8 & 0.0370 & 5.70 & 0.61 & 3.05 & 3.67 & 5.91 & 1.12 & 15571 & 831 & 0.08 & 1.36 & & 0.284 & \\
\hline 99 & Shaw & & 0.31 & 8 & 0.0370 & 12.70 & 0.85 & 4.90 & 5.77 & 6.56 & 1.23 & 31516 & 1044 & 0.13 & 2.14 & & 0.390 & \\
\hline 100 & Shaw & & 0.31 & 8 & 0.0370 & 17.00 & 0.80 & 7.00 & 8.24 & 5.17 & 0.96 & 38198 & 1250 & 0.19 & 3.05 & & 0.460 & \\
\hline 101 & Shaw & & 0.31 & 8 & 0.0370 & 17.00 & 0.96 & 5.80 & 6.79 & 6.84 & 1.27 & 40380 & 1131 & 0.15 & 2.51 & & 0.457 & \\
\hline 102 & Shaw & & 0.31 & 8 & 0.0370 & 24.90 & 0.83 & 9.80 & 11.61 & 4.52 & 0.85 & 49699 & 1477 & 0.26 & 4.30 & & 0.558 & \\
\hline 103 & Shaw & & 0.31 & 8 & 0.0370 & 11.30 & 0.86 & 4.30 & 5.07 & 7.09 & 1.33 & 28903 & 977 & 0.12 & 1.88 & & 0.338 & \\
\hline 104 & Simon et al & T3 47 & 2.44 & 0.27 & 0.0028 & 617.02 & 1.32 & 19.20 & 654.59 & 18.94 & 0.96 & 252845 & 19 & 1.115 & 37.29 & $2.55 \mathrm{E}+01$ & 1.036 & 0.015 \\
\hline 105 & Simon et al & T3 48 & 2.44 & 0.27 & 0.0049 & 614.19 & 1.40 & 17.98 & 630.14 & 15.48 & 1.06 & 252139 & 24 & 1.881 & 53.86 & $4.84 \mathrm{E}+01$ & 1.433 & 0.046 \\
\hline 106 & Simon et al & T3 39 & 2.44 & 0.27 & 0.0081 & 614.76 & 1.50 & 16.76 & 597.47 & 13.25 & 1.17 & 251907 & 31 & 2.941 & 73.52 & $1.53 \mathrm{E}+02$ & 1.524 & 0.055 \\
\hline 107 & Simon et al & T3 41 & 2.44 & 0.27 & 0.0095 & 436.36 & 1.30 & 13.72 & 494.97 & 11.65 & 1.12 & 178931 & 30 & 2.847 & 68.37 & $1.35 \mathrm{E}+02$ & 1.341 & 0.037 \\
\hline 108 & Simon et al & T4 26 & 2.44 & 0.28 & 0.0033 & 439.19 & 1.18 & 15.24 & 513.17 & 17.30 & 0.97 & 180232 & 19 & 1.018 & 32.93 & $1.82 \mathrm{E}+01$ & 0.762 & 0.018 \\
\hline 109 & Simon et al & T4 32 & 2.44 & 0.28 & 0.0047 & 616.17 & 1.43 & 17.68 & 594.60 & 16.32 & 1.09 & 252715 & 25 & 1.695 & 49.31 & $5.31 \mathrm{E}+01$ & 1.036 & 0.021 \\
\hline 110 & Simon et al & T4 27 & 2.44 & 0.28 & 0.0053 & 438.06 & 1.37 & 13.11 & 445.11 & 17.02 & 1.21 & 179767 & 23 & 1.437 & 40.27 & $4.14 \mathrm{E}+01$ & 0.945 & 0.043 \\
\hline 111 & Simon et al & T4 31 & 2.44 & 0.28 & 0.0059 & 604.28 & 1.45 & 17.07 & 580.31 & 14.95 & 1.12 & 247642 & 27 & 2.086 & 56.75 & $6.45 \mathrm{E}+01$ & 1.158 & 0.067 \\
\hline 112 & Simon et al & T4 35 & 2.44 & 0.28 & 0.0082 & 604.00 & 1.50 & 16.46 & 566.28 & 13.28 & 1.18 & 247326 & 32 & 2.793 & 70.30 & 1.37E+02 & 1.829 & 0.076 \\
\hline 113 & Simon et al & T4 37 & 2.44 & 0.28 & 0.0082 & 236.16 & 1.06 & 9.14 & 318.24 & 12.52 & 1.12 & 96991 & 24 & 1.581 & 39.51 & $3.86 \mathrm{E}+01$ & 0.914 & 0.040 \\
\hline 114 & Simon et al & T4 38 & 2.44 & 0.28 & 0.0093 & 432.12 & 1.45 & 12.19 & 421.46 & 13.97 & 1.33 & 177259 & 29 & 2.370 & 57.32 & $1.28 \mathrm{E}+02$ & 1.372 & 0.043 \\
\hline 115 & Simon et al & T4 36 & 2.44 & 0.28 & 0.0101 & 605.41 & 1.43 & 17.37 & 600.45 & 11.08 & 1.09 & 248358 & 36 & 3.668 & 86.70 & $2.11 \mathrm{E}+02$ & 1.737 & 0.037 \\
\hline 116 & Simon et al & T5 39 & 2.44 & 0.45 & 0.0036 & 584.46 & 1.44 & 16.76 & 343.21 & 19.50 & 1.12 & 240665 & 33 & 0.761 & 23.46 & $9.33 \mathrm{E}+00$ & 1.128 & 0.030 \\
\hline 117 & Simon et al & T5 28 & 2.44 & 0.45 & 0.0037 & 316.87 & 1.07 & 12.19 & 257.25 & 16.51 & 0.98 & 130807 & 29 & 0.569 & 17.94 & $5.40 \mathrm{E}+00$ & 0.792 & 0.015 \\
\hline 118 & Simon et al & T5 31 & 2.44 & 0.45 & 0.0043 & 420.51 & 1.29 & 13.41 & 281.09 & 17.66 & 1.13 & 173320 & 33 & 0.735 & 21.85 & $8.05 \mathrm{E}+00$ & 0.975 & 0.018 \\
\hline 119 & Simon et al & T5 41 & 2.44 & 0.45 & 0.0047 & 612.21 & 1.54 & 16.46 & 339.07 & 18.36 & 1.21 & 253347 & 38 & 0.958 & 28.12 & $1.07 \mathrm{E}+01$ & 1.189 & 0.043 \\
\hline 120 & Simon et al & T5 35 & 2.44 & 0.45 & 0.0049 & 158.01 & 0.85 & 7.62 & 164.78 & 14.24 & 0.99 & 65032 & 27 & 0.492 & 14.08 & $2.94 \mathrm{E}+00$ & 0.671 & 0.021 \\
\hline
\end{tabular}




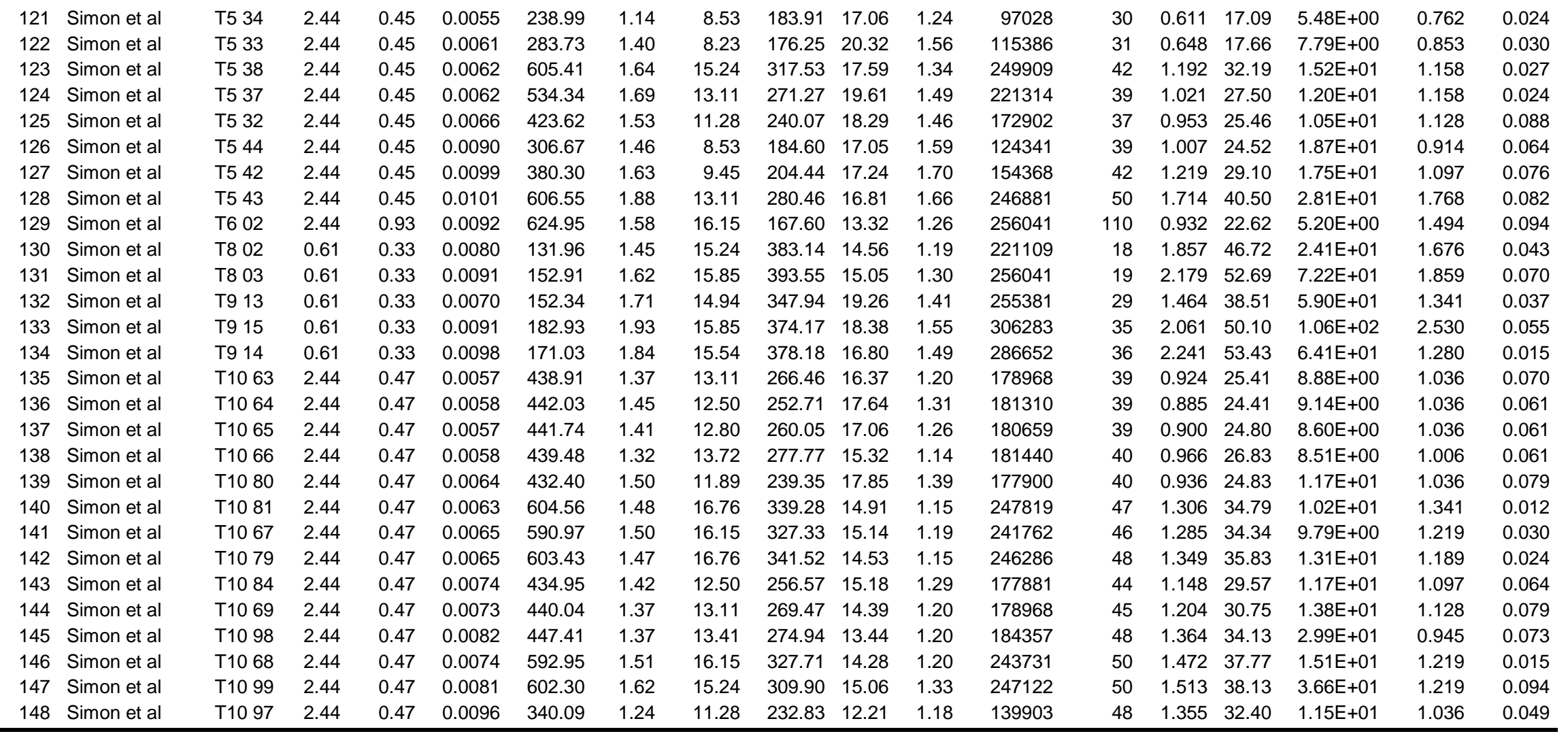




\begin{tabular}{lcc}
\hline Model & Eq.14 & Eq.11 \\
\hline Steep slope data & 0.47 & 0.24 \\
( $\mathrm{S} \geq 1 \%, 72$ values $)$ & $\left(\mathrm{R}^{2}=0.78\right)$ & $\left(\mathrm{R}^{2}=0.95\right)$ \\
Gentle slope data & 0.35 & 0.29 \\
( $\mathrm{S}<1 \%, 76$ values $)$ & $\left(\mathrm{R}^{2}=0.89\right)$ & $\left(\mathrm{R}^{2}=0.93\right)$ \\
All data & 0.40 & 0.28 \\
(148 values) & $\left(\mathrm{R}^{2}=0.85\right)$ & $\left(\mathrm{R}^{2}=0.94\right)$ \\
\hline
\end{tabular}

Table 3: Relative root mean square error for model efficiency comparison

553

554

555

\begin{tabular}{ccccccccccccc}
\hline $\begin{array}{c}W \\
(\mathrm{~m})\end{array}$ & $\begin{array}{c}D \\
(\mathrm{~mm})\end{array}$ & $S$ & $\begin{array}{c}Q \\
(\mathrm{l})\end{array}$ & $\begin{array}{c}U \\
(\mathrm{~m} / \mathrm{s})\end{array}$ & $\begin{array}{c}H \\
(\mathrm{~cm})\end{array}$ & $R_{b} / D$ & $U / u^{*}{ }_{c}$ & $F$ & $\theta$ & $\theta / \theta_{c}$ & $\begin{array}{c}L \\
(\mathrm{~m})\end{array}$ & $A / L$ \\
\hline 0.1 & 4.9 & 0.05 & 0.80 & 0.49 & 1.63 & 3.18 & 5.61 & 1.22 & 0.10 & 1.53 & 0.16 & 0.0309 \\
0.1 & 4.9 & 0.05 & 0.90 & 0.51 & 1.76 & 3.42 & 5.62 & 1.23 & 0.11 & 1.69 & 0.17 & 0.0287 \\
0.1 & 4.9 & 0.05 & 1.05 & 0.53 & 1.98 & 3.83 & 5.52 & 1.20 & 0.12 & 1.85 & 0.19 & 0.0256 \\
0.1 & 4.9 & 0.05 & 1.20 & 0.57 & 2.11 & 4.05 & 5.78 & 1.25 & 0.13 & 1.94 & 0.20 & 0.0242 \\
0.1 & 4.9 & 0.05 & 1.30 & 0.57 & 2.28 & 4.38 & 5.55 & 1.21 & 0.14 & 2.08 & 0.22 & 0.0224 \\
0.1 & 4.9 & 0.05 & 1.50 & 0.60 & 2.50 & 4.78 & 5.60 & 1.21 & 0.15 & 2.29 & 0.24 & 0.0205 \\
0.1 & 4.9 & 0.05 & 1.70 & 0.63 & 2.70 & 5.14 & 5.67 & 1.22 & 0.16 & 2.46 & 0.26 & 0.0191 \\
0.1 & 4.9 & 0.05 & 2.00 & 0.69 & 2.90 & 5.47 & 6.02 & 1.29 & 0.17 & 2.60 & 0.27 & 0.0179 \\
\hline
\end{tabular}

Table 4 : Increasing flow conditions for the experiment presented in Figure 3 and antidune wavelengths calculated with Eq.11. The Steepness A/L was calculated by assuming a constant antidune height equals the grain diameter $4.9 \mathrm{~mm}$. 


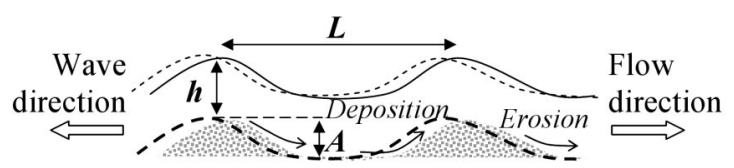

Figure 1 : Schematic presentation of antidunes characterized by a sediment wave migration in the upstream direction and a bed surface in phase with the form of the water surface.

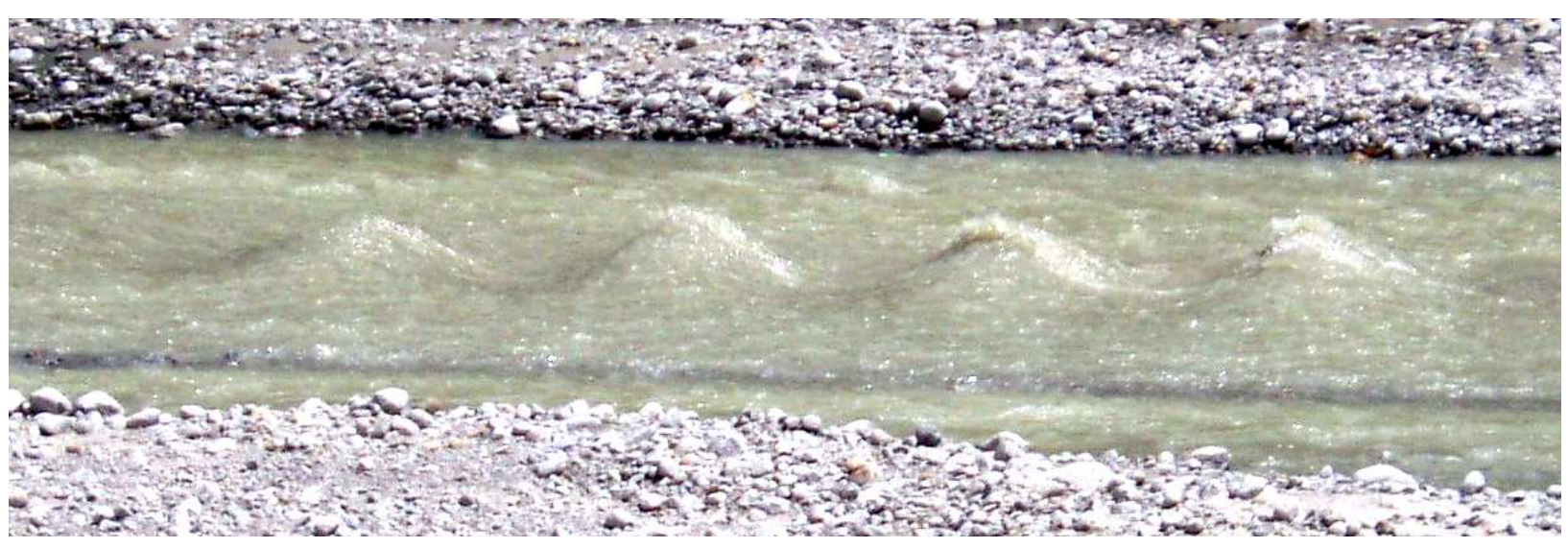

Figure 2: Antidunes on the Arveyron river, a 3\% slope gravel bed river in Chamonix (France). The wavelength was approximately $2 \mathrm{~m}$.

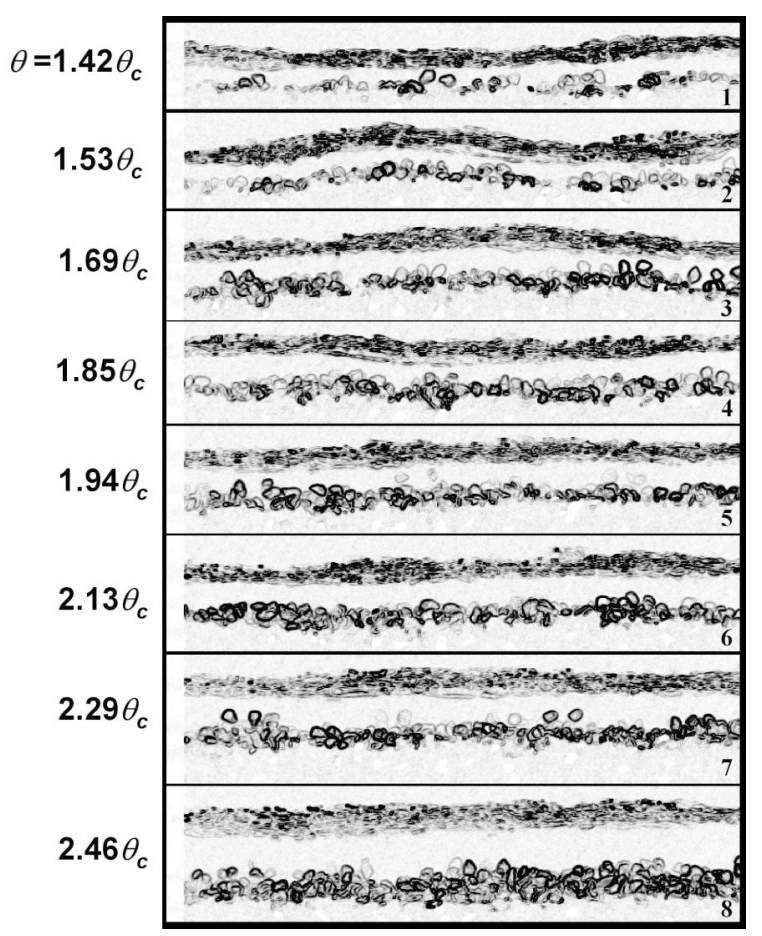

Figure 3 : Images of antidunes for increasing flow conditions characterized by the ratio $\theta / \theta_{c}$. Each image presents the free surface and the moving grains. 


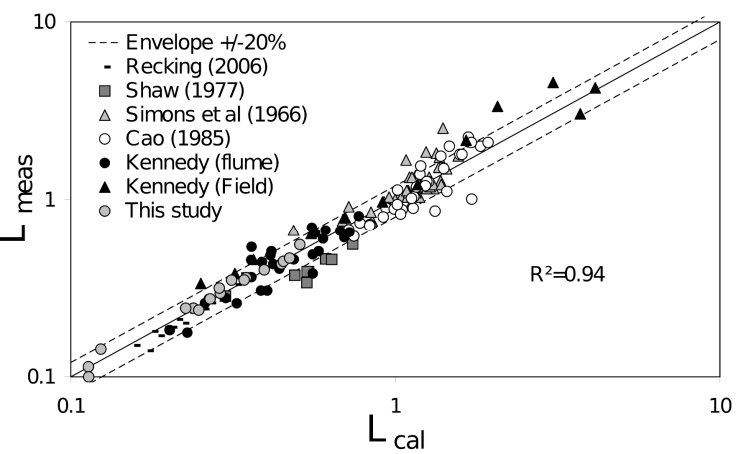

Figure 6: Comparison between computed (with Eq.11) and measured wavelengths (77\% of the values are within the envelop $\pm 20 \%$ )

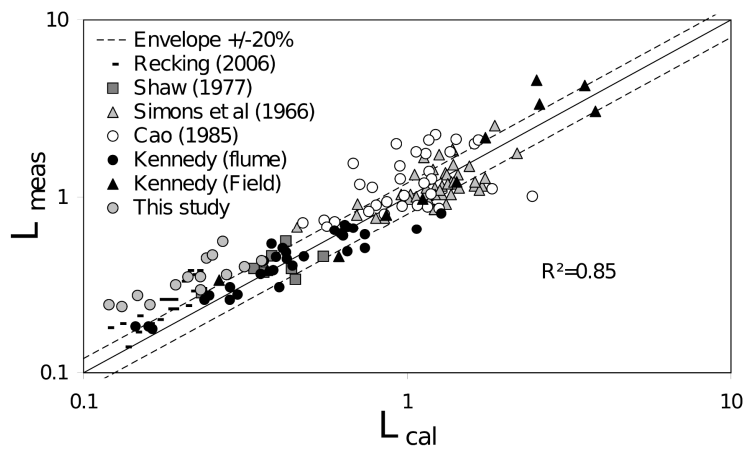

Figure 7: Comparison between computed (with Eq.14) and measured wavelengths (51\% of the values are within the envelop $\pm 20 \%$ ) 


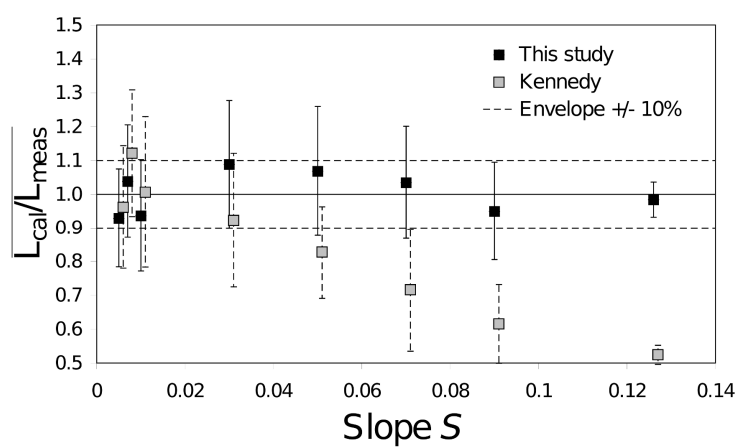

Figure 8: Calculated to measured wavelength ratio for each model and different slopes (each points represent a slope range, from left to right: $S<0.005-0.007-0.01-0.03-0.05-0.07-$ $0.09-0.12$ ). Vertical lines represent the standard deviation.

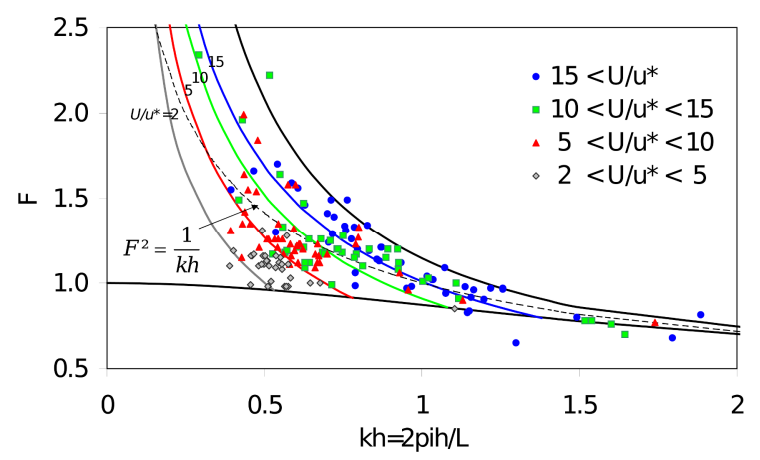

Figure 9 : Wavelengths in the F-kh plane with consideration of $U / \mathrm{u}^{*}$ values

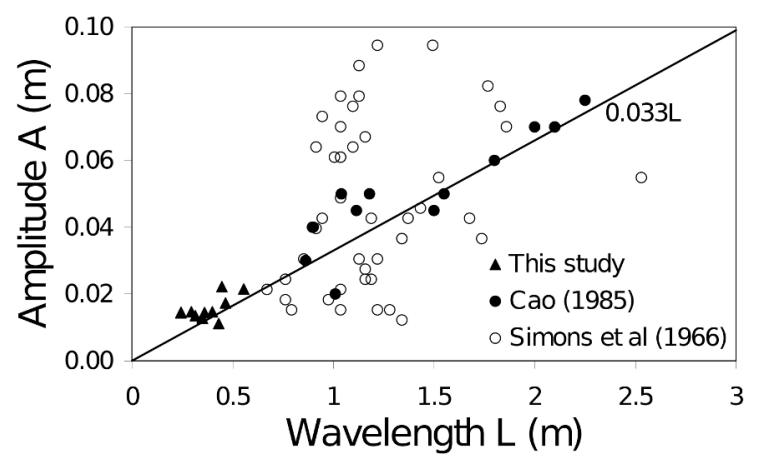

Figure 10: Amplitude versus wavelengths 